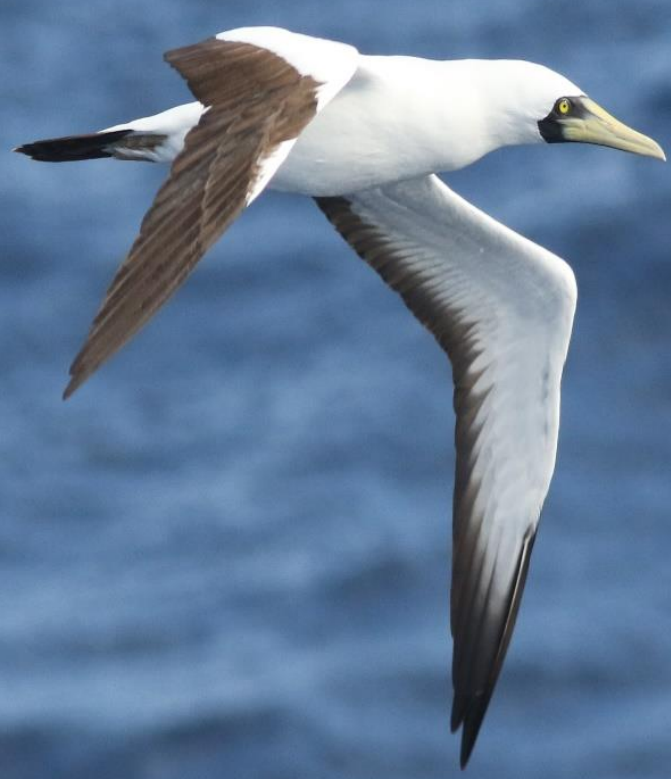

\title{
Caribbean Pelagic Seabird Map Project September 2020 Status Report
}

Author(s): A.O. Debrot ${ }^{1,2}$, N.H.B.M. Kaag ${ }^{1}$, M.F. Leopold ${ }^{1}$, J.T. van der Wal ${ }^{1}$, R. van Halewijn, D.M.C. Poppe, H. Verdaat ${ }^{1}$, I. Bazuin ${ }^{3}$, P.J.F.M. Verweij ${ }^{4}$, M.N. de Boer ${ }^{1}$

${ }^{1}$ Wageningen Marine Research

2 Marine Animal Ecology, Wageningen University

3 HASS Hogeschool, 's Hertogenbosch

${ }^{4}$ Wageningen Environmental Research
Wageningen University \&

Research report C080/20 


\section{Caribbean Pelagic Seabird Map Project: September 2020 Status Report}

Authors: $\quad$ A.O. Debrot ${ }^{1,2}$, N.H.B.M. $\mathrm{Kaag}^{1}$, M.F. Leopold ${ }^{1}$, J.T. van der Wal ${ }^{1}$, R. van Halewijn, D.M.C. Poppe, H. Verdaat ${ }^{1}$, I. Bazuin ${ }^{3}$, P.J.F.M. Verweij ${ }^{4}$, M.N. de Boer ${ }^{1}$

1: Wageningen Marine Research

2: Marine Animal Ecology, Wageningen University

3: HASS Hogeschool, 's Hertogenbosch

4: Wageningen Environmental Research 
Keywords: Caribbean pelagic seabird, Dutch Caribbean EEZ, seabird distribution, records, sightings, GIS map

Client: $\quad$ 1) Kennis Basis programme: KB36 Biodiversity in a Nature Inclusive Society project KB 36-005-002; and 2) Beleids Ondersteuning/Policy Support project BO 43-021.04-004.

KB 36-005-002 en BO-43-021.04-004

This report can be downloaded for free from https://doi.org/10.18174/531515

Wageningen Marine Research provides no printed copies of reports

Wageningen Marine Research is ISO 9001:2015 certified.

Cover photo: Mardik Leopold

\section{(C) Wageningen Marine Research}

Wageningen Marine Research, an institute Wageningen Marine Research accepts no liability for consequential damage, nor within the legal entity Stichting for damage resulting from applications of the results of work or other data Wageningen Research (a foundation under obtained from Wageningen Marine Research. Client indemnifies Wageningen Dutch private law) represented by Dr. Marine Research from claims of third parties in connection with this application. M.C.Th. Scholten, Managing Director All rights reserved. No part of this publication may be reproduced and / or

KvK nr. 09098104, published, photocopied or used in any other way without the written permission WMR BTW nr. NL 8113.83.696.B16.

Code BIC/SWIFT address: RABONL2U IBAN code: NL 73 RABO 0373599285 


\section{Summary}

$1 \quad$ Introduction $\quad 5$

$2 \quad$ Area covered $\quad 7$

$\begin{array}{lll}2.1 & \text { Geography } & 7\end{array}$

2.2 Oceanography $\quad 8$

3 Data sources $\quad 9$

3.1 Databases incorporated 9

3.2 Literature sources $\quad 9$

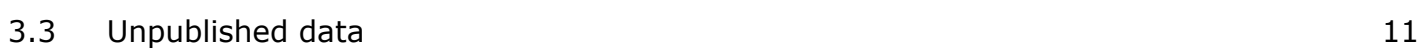

$4 \quad$ Results $r 12$

4.1 Database description $\quad 12$

4.2 Some preliminary patterns apparent $\quad 15$

$5 \quad$ Conclusions and recommendations $r$

$\begin{array}{lr}\text { Acknowledgments } & 19\end{array}$

$\begin{array}{lr}\text { References } & 20\end{array}$

$\begin{array}{lr}\text { Justification } & 23\end{array}$ 


\section{Summary}

Even though there are very many scattered seabird sighting records for the pelagic waters of the wider Caribbean Sea, only few studies bring these data together to generate a more comprehensive understanding of seabird use of the offshore areas of the region. The same is the case for the Dutch Caribbean EEZ which amounts to about 92 thousand $\mathrm{km}^{2}$ of the Caribbean Sea. As a consequence, information on seabird use of offshore waters has been identified as a key knowledge gap and research priority for both EEZ conservation and management purposes (Jongman et al. 2010, Meesters et al. 2010) and in support of a Bonaire-Curacao UNESCO World Heritage nomination that has been a Bonaire government ambition since 2003 (Debrot et al. 2017).

In this project we followed up on these information needs by compiling many older but as-yet unpublished seabird records around the Dutch Caribbean islands, the eastern Caribbean as well as many poorly accessible seabird records for the waters off the coasts of Colombia and Venezuela. The most important additions of previously unavailable or new records for the eastern Caribbean were as follows: 1824 records by Poppe (1974), 627 by Halewijn (1972), 443 recent records by M. de Boer and J. Saulino (2014) all principally for the waters of the Dutch Caribbean, 547 records from Casler and Lira (1979) and Casler and Pirela (2004) for the northwestern sector of Venezuela and 249 records by Naranjo (1979) and Estela et al. (2004) for the Caribbean coast of Colombia. These were subsequently merged with several smaller and larger sources of seabird sighting records to yield a current total compilation of 150,372 sighting records with either exact or approximate position determinations.

The database provides temporal and positional occurrence information for 65 nominate species and 13 larger familial or generic species groups in the Caribbean basin. As such, it provides a major new opportunity for the WUR to study and publish on various aspects of seabird distribution in the coming years. The potential topics include: 1 ) the community composition of the pelagic seabirds of the Caribbean in comparison with the community structure of other pelagic seabird communities, 2) how different habitat features (such as upwelling areas, proximity of nesting and/or roosting areas) are used by different species, 3 ) the identification of temporal trends in seabird species distribution and abundance, 4) identification of areas deserving conservation and management priority, either around seabird colonies or at the high seas. 


\section{Introduction}

Even though there are many scattered seabird sighting records for the open waters of the Caribbean, very little is known about the use of those waters by the seabirds of the region. This is also the case for the seabirds in the offshore areas of the Dutch Caribbean EEZ, which is composed of two distinct sectors of the Caribbean and amounts to about $92,000 \mathrm{~km}^{2}$ of pelagic deep-water habitat (Figure 1). Most available insights for the offshore deep water EEZ areas as well as the Saba Bank are based upon observations made during the hydrographical expeditions on the HMS Luymes in 1971 and 1972 (van Halewijn 1972, Poppe 1974), and observations made in April and May 1996 during bathymetric charting of the Saba Bank with the HNLMS Tydeman (Postma \& Nijkamp 1996). These results have never been worked out in detail and have never been formally published, but nevertheless represent a rich potential source of information. As a consequence, information on seabird use of offshore waters has been identified as a key knowledge gap and research priority for both EEZ conservation and management purposes (Jongman et al. 2010, Meesters et al. 2010) and in support of a BonaireCuracao UNESCO World Heritage nomination that has been a Bonaire government ambition since 2003 and more recently also of Curaçao (Debrot et al. 2017).

Seabird densities in the Caribbean are probably substantially lower than in former times (McGowan et al. 2006) because of overharvesting of seabird colonies until recently. Factors that are likely to affect seabird population sizes today are 1) the availability and quality of nesting habitat, 2) human competition for fish, 3) discard practices by the fishing industry, 4) mortality due to oil spills, 5) net entanglement, and 6) bioaccumulation of anthropogenic contaminants and toxins through the food chain (McGowan et al. 2006). Direct human predation, which used to be widespread, is now illegal in most countries in the Caribbean and likely to be only a minor threat to seabirds in general (e.g., Debrot et al. 2009). Recent surveys on the breeding seabirds of the Dutch Caribbean islands are available for all six islands (Bradley \& Norton 2009). The offshore pelagic habitat may be of importance as a foraging and staging area for several pelagic seabirds (Murphy 2000) but this remains unexplored.

Most bird-watching, professionally as well as leisurely, is land-based and information on offshore presence of sea birds in the Caribbean has remained mostly anecdotal. Dedicated offshore surveys are scarce and often published in so-called grey-literature (survey reports, theses, etc.) or not at all and remain largely unavailable for analysis. Some of the early data were summarized by Voous (1955, 1983), but is strongly focused on the occurrence of birds (all birds) on and around the islands of the Dutch Antilles. The goal of this project was to compile sighting records of seabirds in the Caribbean Sea, from as many sources as possible and build a database to be used to yield deeper understanding of the distribution of seabirds in the pelagic environments of the Caribbean. Data from the wider Caribbean outside the Dutch EEZ areas were included as they are also essential for comparison in order to properly evaluate the potential role significance of the Dutch Caribbean EEZ waters (ie. "Comparative Analysis", sensu the UNESCO World heritage programme, see Debrot et al. 2017). Such a source for a "Caribbean pelagic seabird mapping program" may form the basis for major new studies on seabird use of Caribbean pelagic waters and for monitoring changes in the pelagic seabird community through time in response to major factors that can be expected to affect their populations in the coming decades, such as climate change (Debrot \& Bugter 2010) or implementation of conservation measures. This report describes the information sources included and the choices made in accepting data and assigning numbers and coordinates. We also give a first description of the type of data, its spatial, temporal and species coverage, and its potential use.

Developing and managing such a database is basic towards providing long-term opportunities for research and management of endangered seabirds in the region. An example of the high potential value of developing such a database is provided by the results of the first two papers published under this initiative The first focused on compiling and analyzing sighting records of the endangered Caribbean endemic Black-capped Petrel, Pterodroma hasitata. In that study the EEZ waters of the 
Leeward Dutch Caribbean (Aruba, Bonaire and Curacao) were found to be part of an important southern Caribbean foraging area for the species (Leopold et al. 2019). The second paper partly funded under this project examined the use of an upwelled colder water eddy by pelagic seabirds (Boog et al. 2019).

Such information is also of particular importance to the longstanding initiative of Bonaire to seek a UNESCO inscription of the Bonaire National Marine Park (BNMP) as a World heritage site. The park has been formally considered for potential World Heritage inscription since 2003 and has been on the inventory of properties suitable for inscription on the World Heritage List (the Tentative List) since 2011 (Debrot et al. 2017). In 2015, an expert group concluded that the BNMP could only attain a successful nomination if it were part of a larger area (Expertgroep 2015). This recommendation was based on two preparatory reports by WMR (formerly IMARES) which outlined the steps needed for a successful nomination (Cremer \& Meesters 2012; Beek et al. 2014a). These included the recommendation that specific consideration should be given to including at least a part of the 12 nautical mile Territorial Sea as part of the proposed nomination. A 12-mile zone seawards extension would:

a) protect an additional 9 primarily-pelagic IUCN Red List species,

b) expand the fish fauna by about 300 primarily pelagic species,

c) incorporate a variety of additional benthic habitats, such as deepwater mesophotic reefs, into the nomination area and also

d) expand the properties to include pelagic areas which contribute significantly to combined ecological resilience which is a key UNESCO World Heritage selection criterium.

A central aim of the UNESCO World Heritage Committee is to achieve a representative, balanced and credible mix of protected areas of "Outstanding Universal Value" (OUV) (Abdullah et al. 2013). However, none of the North Western Atlantic marine pelagic biogeographic provinces yet has any marine World Heritage sites. The addition of a large pelagic zone of the Inter American Seas Pelagic Province (in which Bonaire and Curaçao lie), to the nomination property could, therefore, significantly strengthen the chances of a successful nomination because it could then help to fill an important biogeographic gap for conservation on the current World Heritage List. Expanding the boundaries of the nomination areas to include pelagic habitat would additionally strengthen the different levels of connectivity and allow for future discovery of new undocumented attributes related to the World Heritage criterium "OUV" (Outstanding Universal Value) produced by any future research. As a consequence, more knowledge of the seabirds of the deep waters surrounding the islands has long been identified as a clear knowledge gap and research priority to address within the World Heritage Nomination initiative (Debrot et al. 2017). 


\section{Area covered}

While our main focus is on the eastern Caribbean, we included data from the central and western Caribbean so as not to limit a more comprehensive assessment. Hence, the area of concern is the Caribbean Sea, roughly delimited by the mainland of Venezuela and Colombia in the South, the coastline from Panama to Yucatan in the West, and the chain of islands from Cuba in the North to Barbados in the East. The Caribbean Sea is heterogeneous in terms of geography and oceanography, both factors which influence marine productivity and help govern the distribution of seabirds and other marine megafauna.

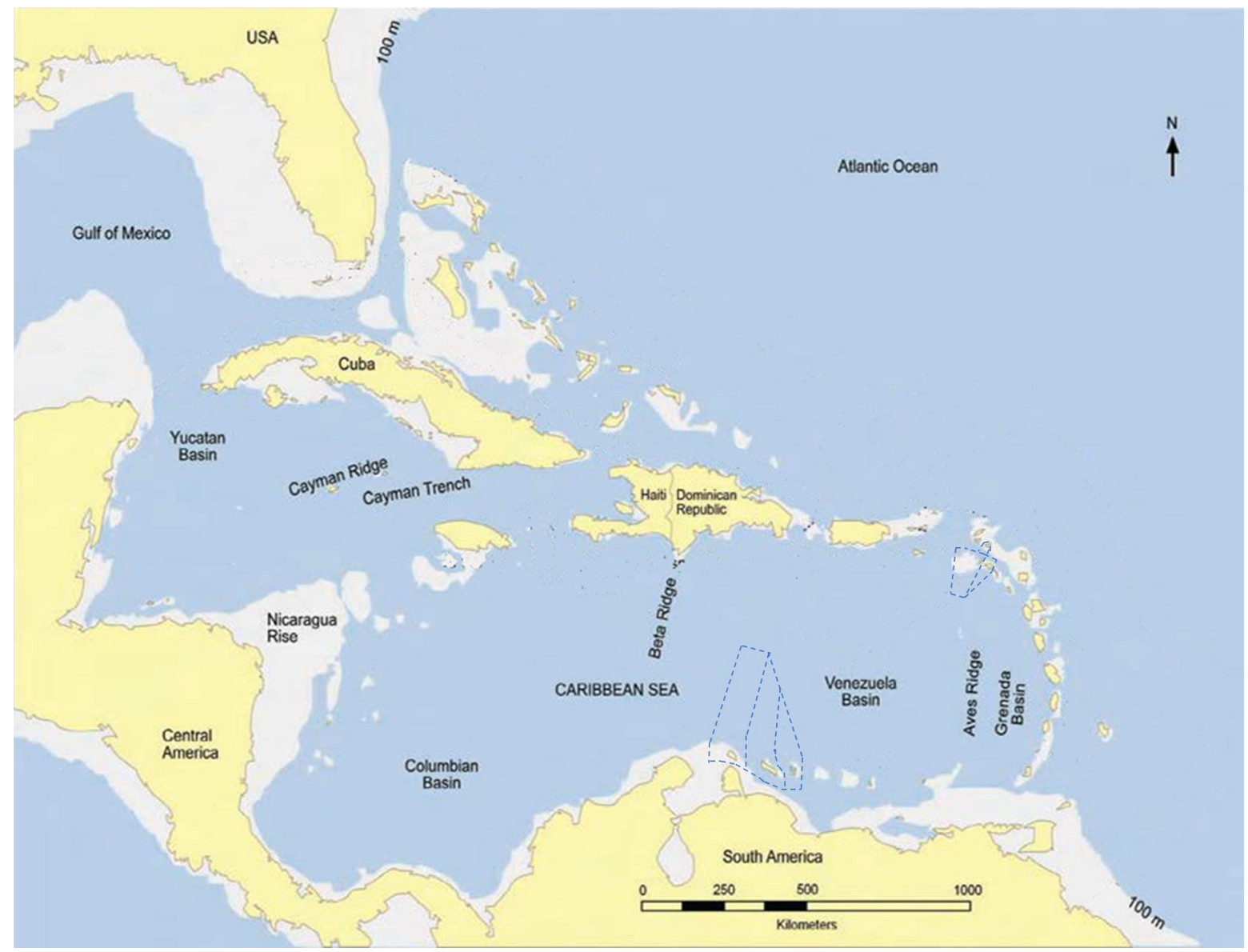

Figure 1. Map of the Caribbean Sea showing the main division into 5 sub-basins (modified from Lutz \& Ginsberg 2007). Dashed lines indicate the positions of the two sectors of the Dutch Caribbean EEZ.

\subsection{Geography}

The Caribbean Sea is composed of five submarine basins (Figure 1). These are sequentially from northwest to southeast the Yucatán, Cayman, Colombian, Venezuelan, and Grenada basins. The Yucatán Basin, is separated from the Gulf of Mexico by The Yucatán Channel, which separates the Caribbean from the Gulf of Mexico and has a sill-depth (lowest height from the bottom of a basin at which water can flow to an adjacent basin) of about 1,600 meters below sea level. The Cayman Basin, is separated from the Yucatán Basin by Cayman Ridge, upon which the Cayman Islands lie. The Colombian basin is separated from the Cayman basin to the north by the Nicaraguan Rise with a silldepth of about 1,200 meters, and which extends from Nicaragua and Honduras to Hispaniola, and on which the island of Jamaica is located. The Beata Ridge next separates the Colombian Basin from the Venezuelan Basin, both of which are connected by the Aruba Gap at depths of more than 4000 
meters. Finally the Aves Ridge separates the Venezuelan Basin from the small Grenada Basin, which is separated from the Atlantic Ocean to the east by the Antillean island chain (Mann 1999, Keith 2005).

\subsection{Oceanography}

The Caribbean surface water originates as a mix of both the North Equatorial Current and the South Equatorial Current, the latter of which is pushed north along the coast of Brazil and the Guayanas (where it is known as the Guayanas Current). Te surface salinity of the Caribbean is greatly influenced by plumes and cyclonic lenses of fresh water originating from the Amazon and the Orinoco (Chérubin \& Richardson 2007). The Caribbean Current, is the main surface circulation in the Caribbean Sea, and moves from east to west at an average speed of about $50 \mathrm{~cm} / \mathrm{sec}$. The water enters the Caribbean from the Atlantic through eastern and north-eastern passages between the islands and ultimately converges and accelerates again into the Gulf Stream in the Straits of Florida (Fratantoni 2001; Gyory et al. 2005; Lutz \& Ginsburg 2007). Surface current velocities are variable depending on widening and or narrowing of the water passages, but are high $(70 \mathrm{~cm} / \mathrm{sec})$ in the southern Caribbean along the Netherlands Antilles (Fratantoni 2001; Gyory et al. 2005; Lutz \& Ginsburg 2007).

Surface water temperatures in the Caribbean are highly stratified in the upper 1200 meters but uniform below 2000 meter. Because of the exchanges with the open Atlantic, there is little seasonal variation in surface water temperatures, ranging from $25.5^{\circ} \mathrm{C}$ in the winter to $28^{\circ} \mathrm{C}$ in the summer (Gyory et al. 2005; Lutz and Ginsburg 2007). Bottom temperatures are close to $4^{\circ} \mathrm{C}$ and salinity is slightly less than 35 ppt.

The southern Caribbean is dominated by a wind-driven upwelling system off the coasts of Venezuela and Colombia. Upwelling is concentrated in two areas, one towards the east $\left(11^{\circ} \mathrm{N}, 64^{\circ} \mathrm{W}\right)$ near the Venezuelan island of Margarita and one towards the east of the peninsula of Guajira ( $12^{\circ} \mathrm{N}, 73^{\circ} \mathrm{W}$ ). The upwelling area off the island of Margarita is the largest and brings nutrient rich waters to the surface that form the basis for the most productive fishery of the Caribbean (Sturm 1991). Eddies of cold, nutrient rich water are known to be formed in the downstream section of this upwelling and may migrate as cold and nutrient-rich nuclei of water well into the Venezuelan basin (e.g. van der Boog et al. 2019). The movement patterns of cetaceans in the leeward Dutch islands suggests that the southern Caribbean upwelling area may play an important role in the migration patterns of marine mammals in the region (Debrot et al. 1999). Additional, but less important areas of upwelling are found off Nicaragua, Honduras and Belize, as well as seasonally between Hispaniola and Puerto Rico (Sturm 1991). All upwelling areas can be expected to be of special importance to large numbers of seabirds and other sea life. 


\section{Data sources}

Data were collected from public and non-public databases. A quick-scan through these data revealed little overlap between the databases. Data were also extracted from literature. Some published in peer-reviewed journals, others as university theses or dissertations. The observations published in these papers is not covered in the databases used, but some of the older records mentioned in these papers can also be found in the databases.

The most important contributions of previously unavailable records for the eastern Caribbean by our data entry were as follows: 1,824 records by Poppe 1974, 627 by Halewijn 1972, 443 recent records by M. de Boer and J. Saulino (2014) all principally for the waters of the Dutch Caribbean inside the Venezuelan Basin, 547 records from Casler \& Lira (1979) and Casler \& Pirela (2004) for the northwestern sector of Venezuela and 249 records by Naranjo (1979) and Estela et al. (2004) for the Caribbean coast of Colombia. These were then merged with several smaller and larger sources of seabird sighting records.

\subsection{Databases incorporated}

1. Global Biodiversity Information Facility (GBIF). From gbif.org 135,775 records were extracted covering the period 1862-2020. GBIF covers a wide range of public data sources, including eBird and iNaturalist records. As no numbers of birds are given, the number of individuals is set as 1 for each record.

2. Observation.org., Stichting Observation International and local partners. From Observation.org 9,835 records were extracted, covering the period 1927-2020.

3. Royal Naval Birdwatching Society (https://www.rnbws.org.uk). From the UK RNBWS 537 records were obtained, covering the period 1947-2020.

4. Wageningen Marine Research (WMR). From the the WMR Caribbean Seabirds at Sea database, 32 previously unpublished records wer incorporated collected during visits to the Saba Bank in 2011 and 2018.

\subsection{Literature sources}

1. Leopold M.F., S.C.V. Geelhoed, M. Scheidat, J. Cremer, A.O. Debrot \& R. van Halewijn (2019). A review of records of the Black-capped petrel Pterodroma hasitata in the Caribbean Sea. Marine Ornithology 47: 227-233. Covering 152 records Black-capped petrel in the period 1953-2018. Overlap with other sources removed.

2. Halewijn R., van (1972). Report on marine ornithology. Southeastern Caribbean Sea and adjacent Atlantic Ocean. MSc Thesis containing survey data from 1970-1972, incl some literature references: 697 survey recs used, as well as 24 records from literature $(<1910-1968)$. Mainly covering SW part of Caribbean and adjacent Atlantic above Guyana's. Locations and date estimated from survey charts and species distribution maps.

3. Poppe D.M.C. (1974). Zeevogelwaarnemingen in het oostelijk deel van de Caraïbische zee (CICAR 1972). MSc Thesis covering survey data in 1972 (414 recs estimated from Table and maps) + notes (1410 recs, locations estimated from date-time and trip. Mainly covering area around lesser Antilles and Puerto Rico and near monthly trips back and forth between Curacao and the survey area.

4. Casler, C. L., \& Lira, J. R. (1979). Censos poblacionales de aves marinas de la costa occidental del Golfo de Venezuela. Bol. Centro Invest. Biol, 13(1), 37-85.

527 records for the Caimare Chico area in Venezuela. 
5. Naranjo Henao L.G. (1979). Las aves marinas del Caribe Colombiano : taxonomía, zoogeografía y anotaciones ecológicas. Tesis de Grado para optar al título de Biólogo Marino. Fundacion Universidad de Bogota Jorge Tadeo Lozano. PhD thesis seabirds Colombia. Containing survey data from period 1977-1979 (208 recs) and collected specimen 1941-1975 (218 recs). Except for rarities, occurrence is described as 'area between' and 'period between'. For these only these locations mentioned were taken, and 1 record for each month in the period given.

6. Digby A., P. Lopez, I. Ribeiro, J. Alarcon \& A. Gartner (2015). Caribbean Colombia: Pelagic bird observations in 2014 and 2015. Conservación Colombiana - Número 23 - octubre 2015.

69 records were used: 16 with exact coordinate, for 53 records coordinates were estimated from distribution maps.

7. Furniss S. (1983). Status of the seabirds of the Culebra Archipelago, Puerto Rico. Colonial Waterbirds, 121-125. 41 records on Nesting data Culebra, Puerto Rico. One coordinate for the area estimated

8. Estela F., L.G. Naranjo \& R. Franke-Ante (2004). Records of Jaegers (Aves: Stercorariidae) from the Colombian coasts. Boletín de Investigaciones Marinas y Costeras-INVEMAR 33(1): 245-250. 31 records of Jaegers. Positions estimated from place names and/or coordinates as provided.

9. Murphy W.L. (2000). Observations of pelagic seabirds wintering at sea in the Southeastern Caribbean. In: Studies in Trinidad and Tobago Ornithology Honouring Richard Ffrench (F. E. Hayes and S. A. Temple, Eds.). Dept. Life Sci., Univ. West Indies, St. Augustine, Occ. Pap. 11. 31 records, 18 with given positions, others estimated from description.

10. Hayes, F. E., \& Samad, I. (2002). Avifauna of the 'dragon's teeth': the Bocas Islands, northern Gulf of Paria, between Venezuela and Trinidad. Dept. Life Sci., Univ. West Indies, St. Augustine, Occ. Pap, 11, 62-85.

22 records from named Bocas islands in the northern Gulf of Paria, between Trinidad and Venezuela.

11. Casler, C. L., \& Pirela, D. (2005). Seasonal Abundance of Parasitic and Pomarine Jaegers (Aves: Stercorariidae) on the Southwestern Coast of the Gulf of Venezuela. Boletín del Centro de Investigaciones Biológicas, 39(2): 145-158.

20 records for a $41 \mathrm{~km}$ transect of the Caimare Chico beach in the Gulf of Venezuela.

12. Luksenburg J.A. \& G. Sangster (2013). New seabird records from Aruba, southern Caribbean, including three pelagic species new for the island. Marine Ornithology 41: 183-186. 17 records with positions given.

13. Sanz V., L. Oviol, Á. Medina \& R. Moncada (2010). Avifauna del estado Nueva Esparta, Venezuela: recuento histórico y lista actual con nuevos registros de especies y reproducción. Interciencia 35(5): 329-339.

16 records with positions given.

14. Shirihai H., M. San Román, V. Bretagnolle \& D. Wege (2010). The Jamaica Petrel Pelagic Expedition. A pelagic expedition off Jamaica, and off the islands of Guadeloupe and Dominica. November-December 2009. Petrels of the Caribbean. 15 records, positions estimated from description.

15. Blokpoel H., C.L. Casler, F. Espinoza, G.D. Tessier \& J.R. Lira B. (1984). Distribution and numbers of large terns in Northwestern Venezuela during 26 January-5 February 1983. For the 15 records used, the geographic center of the given area was taken.

16. Sanz V. \& L. Oviol (2010). Aves del archipiélago Los Frailes (Venezuela), con nuevos registros de especies y reproducción. Mem. Fund. La Salle de Cienc. Nat. 172: 97-102. 14 species with positions given.

17. Levesque A. \& M.E. Jaffard (2002). Fifteen new bird species in Guadeloupe (FWI). Journal of Caribbean Ornithology, 15(1): 5-6.

6 records, Positions estimated from description.

18. Giner, S. B. (2012). Anidación de la Gaviota Filico (Sternula antillarum) y el Playero Picogrueso (Charadrius wilsonia cinnamominus) en las costas del estado Falcón. Journal of Caribbean Ornithology, 25(1): 24-30.

4 records of nesting locations of terns for Falcón state in Venezuela.

19. Mlodinow S.G. \& R.L. Norton (2017). First record of Red-billed Tropicbird (Phaethon aethereus) for Aruba. The Journal of Caribbean Ornithology. Vol. 30(2): 143-144.

2 records, positions estimated. 
20. Dugand, A. (1947). Aves marinas de las costas e islas Colombianas. Caldasia: 379-398. 1 record, position estimated.

21. Manolis, T. (1981). First sight record of South Polar Skua Catharacta maccormicki for Trinidad, West Indies. Amer. Birds 35:982. 1 record. position estimated.

22. Naranjo L.G. (2010). Dos registros desapercibidos de aves marinas en Colombia. Boletín SAO Vol. 20: $39-41$.

1 record, position estimated.

23. Prins, T.G., J.H. Reuter, A.O. Debrot, J. Wattel \& V. Nijman, (2009). Checklist of the birds of Aruba, Curacao, and Bonaire, South Caribbean. Ardea 97: 137-262, and Voous, K. H. 1983. Birds of the Netherlands Antilles. Walburg Pers. 22 additional records combined

24. Van der Boog, C. G., de Jong, M. F., Scheidat, M., Leopold, M. F., Geelhoed, S. C. V., Schulz, K., Dijkstra, H.A, Pietrzak, J. D., \& Katsman, C. A. (2019). Hydrographic and biological survey of a surface-intensified anticyclonic eddy in the Caribbean Sea. Journal of Geophysical Research: Oceans, 124(8), 6235-6251; 116 records.

\subsection{Unpublished data}

De Boer, M. N., and J.T. Saulino made 443 sighting records available collected during a two month geophysical survey (Repsol Exploration Aruba S.A.) in August and September 2014 for a $8500 \mathrm{~km}^{2}$ area north of Aruba. 


\section{$4 \quad$ Results}

\subsection{Database description}

The combined database now provides 150,372 records of sea bird species, covering the whole of the Caribbean area (Figure 2 for records in the 20th century in 3 periods and Figure 2 for records in the 21 st century by year). The data cover the period 1882 to 2020 . Pelagic observations of seabirds really only began in earnest after the 1950s (Figure 2) and the data available until 1999 also were largely concentrated in the eastern Caribbean (Figure 2). Since the year 2000, it can be seen that seabird observations have been much more widely spread throughout the Caribbean and have continued to increase steadily (Figure 3). This can likely be attributed to the popularization of birdwatching, the availability of cameras allowing records to be reliably assessed by experts and online databases encouraging naturalists to submit their observations for inclusion in online databases. For 11 records, no year is known, while for another 15 records only a period is recorded $(<1910,1970-1971,1996$ $1998,1997-1998)$. For the majority of records $(150,346)$ at least the recording year, but most often also month and day are known. The data have a number of limitations. For instance, two major limitations applying to the bulk of records originating from the GBIF are that they are only so-called presence/absence records (no actual counts) and that most records have been contributed by amateur observers such that large, unmistakable species like the Frigate bird (amounting to about $30 \%$ of all records combined) predominate and means that other species are likely greatly neglected in representation. The limitations inherent to the various data sources used, will need to be taken into account when quantitative analysis is to be done. When combining databases there is also the potential for overlap and unintentional double reporting of certain records. In this work we are keen on this problem but a case-by-case screening for potential double-counted records will be needed once detailed analysis is undertaken.

In both periods, as can be expected, the majority of data is concentrated in coastal areas. The surveys in the early seventies (by Halewijn 1972, Poppe 1974) clearly stand out as a two concentrations of records around the leeward and respectively windward Dutch islands and a $600 \mathrm{~km}$ track of records connecting the two island groups, (Figure 1). The distribution of clear offshore records is more evenly distributed in the last decade, with also more sightings in the western Caribbean (Figure 3 ).

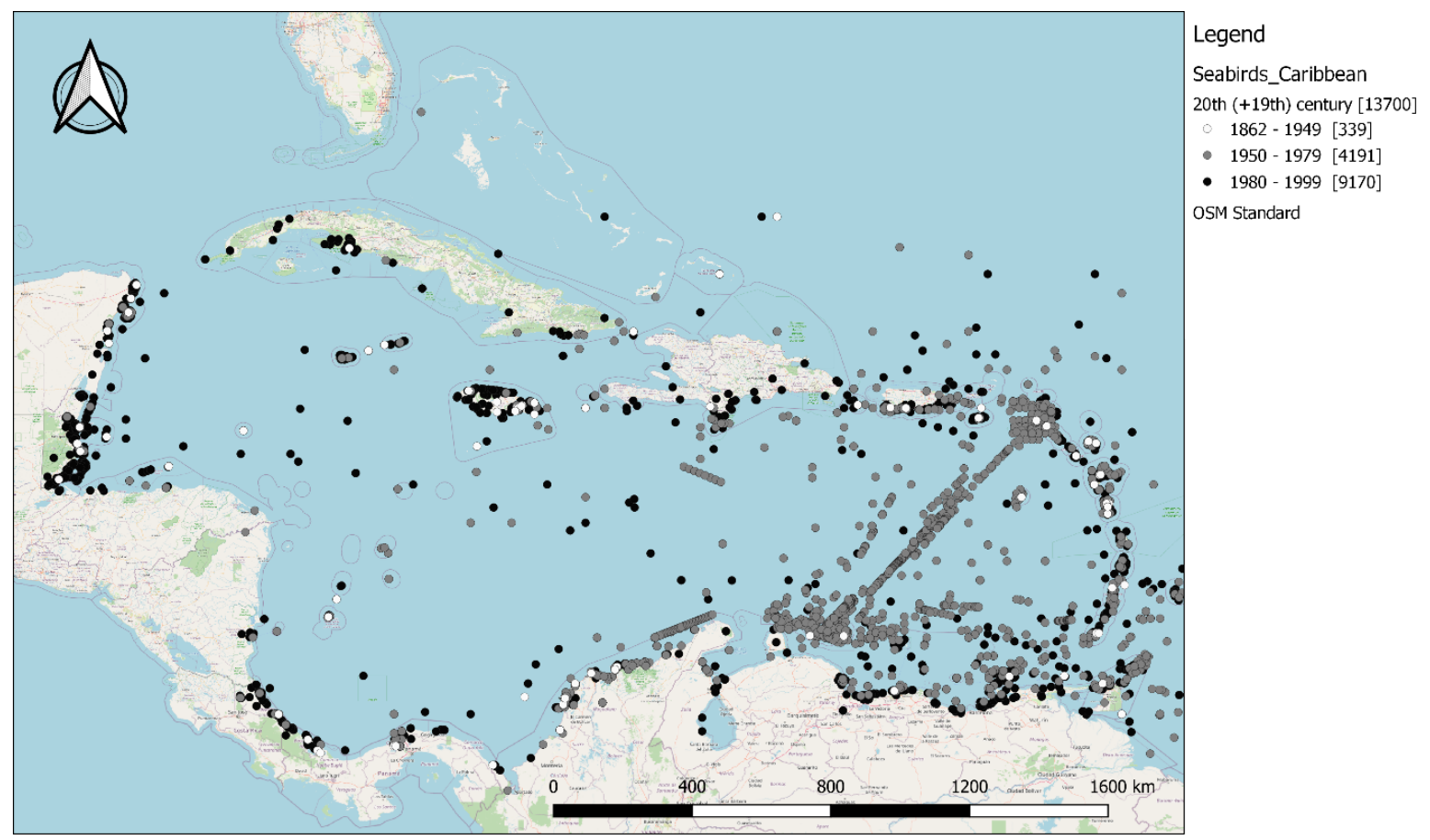

Figure 2. Map showing records of sea birds in the Caribbean and adjacent waters in the $20^{\text {th }}$ century. 
Table 1. Preliminary list of species documented, followed by number of records, IUCN Redlist status and SPAW II listing.

\begin{tabular}{|c|c|c|c|c|c|}
\hline English name & Scientific name & Family & $\begin{array}{l}\text { Number } \\
\text { of } \\
\text { records }\end{array}$ & $\begin{array}{l}\text { IUCN } \\
\text { Redlist } \\
\text { status }\end{array}$ & SPAW II \\
\hline Atlantic yellow-nosed albatross & Thalassarche chlororhynchos & Diomedeidae & 1 & $E$ & \\
\hline Black-browed albatross & Thalassarche melanophris & Diomedeidae & 3 & LC & \\
\hline Magnificent frigatebird & Fregata magnificens & Fregatidae & 58827 & LC & \\
\hline Great frigatebird & Fregata minor & Fregatidae & 9 & LC & \\
\hline Frigatebird sp. & Fregata sp. & Fregatidae & 4 & - & \\
\hline Band-rumped storm-petrel & Oceanodroma castro & Hydrobatidae & 8 & LC & \\
\hline Leach's storm-petrel & Oceanodroma leucorhoa & Hydrobatidae & 95 & VU & \\
\hline Storm-petrel sp. & Oceanodroma sp. & Hydrobatidae & 4 & - & \\
\hline Herring gull & Larus argentatus & Laridae & 3 & LC & \\
\hline Mew gull & Larus canus & Laridae & 1 & LC & \\
\hline Ring-billed gull & Larus delawarensis & Laridae & 53 & LC & \\
\hline Kelp gull & Larus dominicanus & Laridae & 2 & LC & \\
\hline Lesser black-backed gull & Larus fuscus & Laridae & 68 & LC & \\
\hline Great black-backed gull & Larus marinus & Laridae & 3 & LC & \\
\hline American herring gull & Larus smithsonianus & Laridae & 47 & LC & \\
\hline Bonaparte's gull & Chroicocephalus philadelphia & Laridae & 3 & LC & \\
\hline Black-headed gull & Chroicocephalus ridibundus & Laridae & 9 & LC & \\
\hline Laughing gull & Leucophaeus atricilla & Laridae & 1187 & LC & \\
\hline Franklin's gull & Leucophaeus pipixcan & Laridae & 5 & LC & \\
\hline Black-legged kittiwake & Rissa tridactyla & Laridae & 3 & LC & \\
\hline Sabine's gull & Xema sabini & Laridae & 1 & LC & \\
\hline Black noddy & Anous minutus americanus & Laridae & 49 & LC & \\
\hline Noddy sp. & Anous sp. & Laridae & 274 & - & \\
\hline Brown noddy & Anous stolidus & Laridae & 1406 & LC & \\
\hline Black tern & Chlidonias niger & Laridae & 1300 & LC & \\
\hline Gull-billed tern & Gelochelidon nilotica & Laridae & 122 & LC & \\
\hline Common white tern & Gygis alba & Laridae & 1 & LC & \\
\hline Sooty tern & Onychoprion fuscatus & Laridae & 1575 & LC & \\
\hline Sooty/Bridled tern & Onychoprion sp. & Laridae & 2 & - & \\
\hline Large-billed tern & Phaetusa simplex & Laridae & 7 & LC & \\
\hline Bridled tern & Onychoprion anaethetus & Laridae & 1106 & LC & \\
\hline Caspian tern & Sterna caspia & Laridae & 193 & LC & \\
\hline Roseate tern & Sterna dougallii & Laridae & 1171 & LC & $\mathrm{Y}$ \\
\hline Forster's tern & Sterna forsteri & Laridae & 14 & LC & \\
\hline Common tern & Sterna hirundo & Laridae & 353 & LC & \\
\hline Arctic tern & Sterna paradisea & Laridae & 46 & LC & \\
\hline Sterna sp. & Sterna sp. & Laridae & 5 & - & \\
\hline Least tern & Sternula antillarum & Laridae & 774 & LC & $\mathrm{Y}$ \\
\hline Royal tern & Thalasseus maximus & Laridae & 32950 & LC & \\
\hline Cabot's tern & Thalasseus sandvincensis acuflavidus & Laridae & 430 & LC & \\
\hline Cayenne tern & Thalasseus sandvincensis eurygnatha & Laridae & 272 & LC & \\
\hline Wilson's storm-petrel & Oceanites oceanicus & Oceanitidae & 113 & LC & \\
\hline White-faced storm-petrel & Pelagodroma marina & Oceanitidae & 1 & LC & \\
\hline American osprey & Pandion haliaetus carolinensis & Pandionidae & 1091 & LC & \\
\hline Western osprey & Pandion haliaetus haliaetus & Pandionidae & 28249 & LC & \\
\hline American white pelican & Pelecanus erythrorhynchos & Pelicanidae & 35 & LC & \\
\hline Brown pelican & Pelecanus occidentalis & Pelicanidae & 1879 & LC & $\mathrm{Y}$ \\
\hline Pelican sp. & Pelecanus sp. & Pelicanidae & 2 & - & \\
\hline Tropicbird sp. & Phaethon sp. & Phaethontidae & 3 & - & \\
\hline Red-billed tropicbird & Phaethon aethereus & Phaethontidae & 400 & LC & \\
\hline White-tailed tropicbird & Phaethon lepturus & Phaethontidae & 1225 & LC & \\
\hline Double-crested cormorant & Phalacrocorax auritus & Phalacrocoracidae & 140 & LC & \\
\hline Olivaceous cormorant & Phalacrocorax brasilianus & Phalacrocoracidae & 361 & LC & \\
\hline Cormorant sp. & Phalacrocorax sp. & Phalacrocoracidae & 1 & - & \\
\hline Bulwer's petrel & Bulweria bulwerii & Procellariidae & 17 & LC & \\
\hline Cory's shearwater & Calonectris diomedea & Procellariidae & 18 & LC & \\
\hline Black-capped petrel & Pterodroma hasitata & Procellariidae & 199 & $E$ & $\mathrm{Y}$ \\
\hline Great shearwater & Puffinus (Ardenna) gravis & Procellariidae & 179 & LC & \\
\hline Sooty shearwater & Puffinus (Ardenna) griseus & Procellariidae & 5 & LC & \\
\hline Audubon's shearwater & Puffinus Iherminieri & Procellariidae & 529 & LC & $\mathrm{Y}$ \\
\hline Manx shearwater & Puffinus puffinus & Procellariidae & 312 & LC & \\
\hline Shearwater sp. & Puffinus sp. & Procellariidae & 4 & - & \\
\hline Red phalarope & Phalaropus fulicarius & Scolopacidae & 4 & LC & \\
\hline Red-necked phalarope & Phalaropus lobatus & Scolopacidae & 126 & LC & \\
\hline Long-tailed jaeger & Stercorarius longicaudus & Stercorariidae & 52 & LC & \\
\hline Parasitic jaeger & Stercorarius parasiticus & Stercorariidae & 324 & LC & \\
\hline Pomarine jaeger & Stercorarius pomarinus & Stercorariidae & 418 & LC & \\
\hline Pomarine/Parasitic jaeger & Stercorarius sp. & Stercorariidae & 36 & - & \\
\hline South polar skua & Stercorarius (Catharacta) maccormicki & Stercorariidae & 6 & LC & \\
\hline Great skua & Stercorarius (Catharacta) skua & Stercorariidae & 28 & LC & \\
\hline Skua sp. & Stercorarius (Catharacta) sp. & Stercorariidae & 1 & - & \\
\hline Skua/Jaeger sp. & Stercorarius sp. & Stercorariidae & 15 & - & \\
\hline Northern gannet & Morus bassanus & Sulidae & 1 & LC & \\
\hline Masked booby & Sula dactylatra & Sulidae & 766 & LC & \\
\hline Brown booby & Sula leucogaster & Sulidae & 9151 & LC & \\
\hline Booby sp. & Sula sp. & Sulidae & 15 & - & \\
\hline Gannet/Booby sp. & Sula sp. & Sulidae & 4 & - & \\
\hline Red-footed booby & Sula sula & Sulidae & 2276 & LC & \\
\hline
\end{tabular}




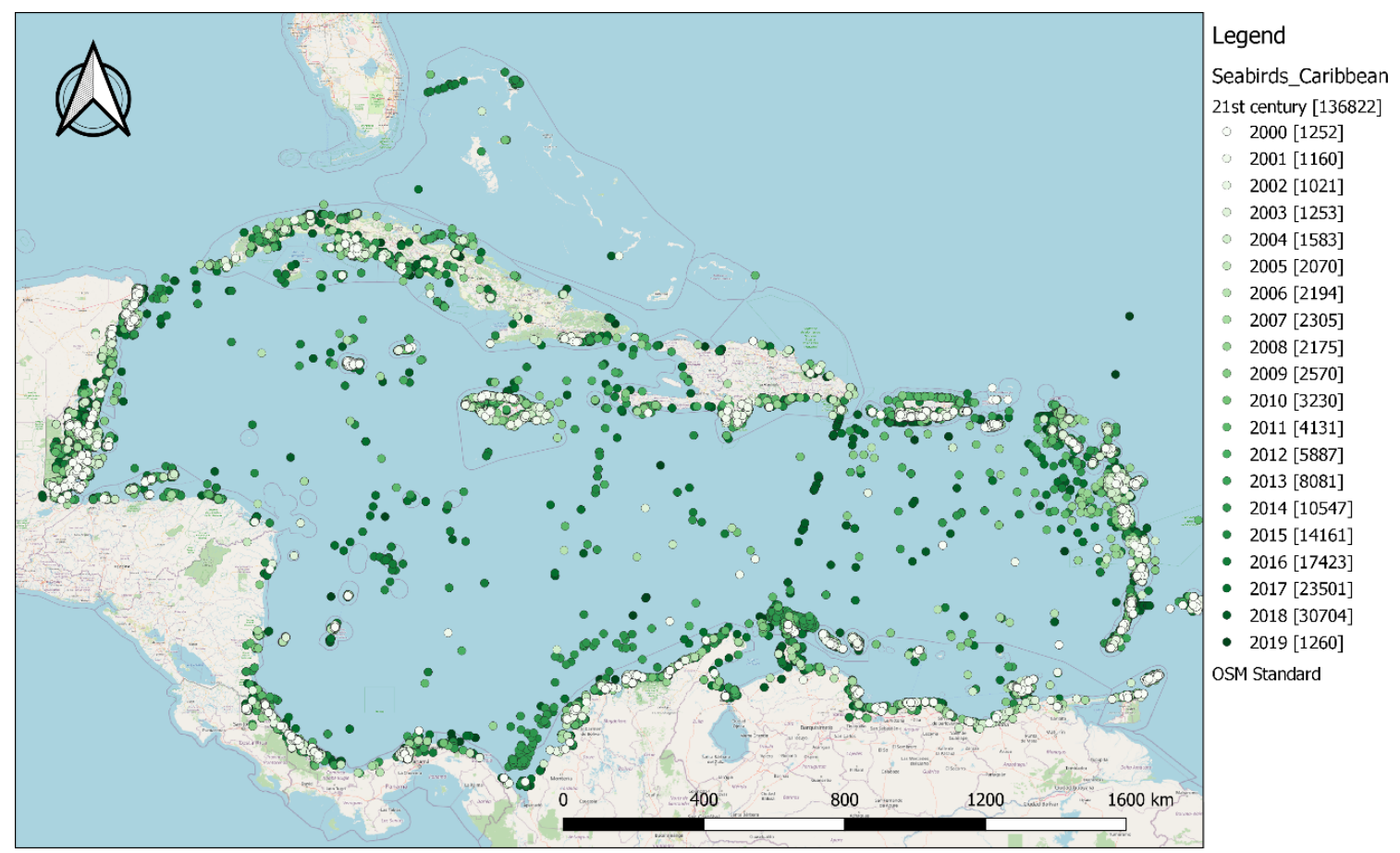

Figure 3. Map showing records of sea birds in the Caribbean and adjacent waters in the $21^{\text {st }}$ century

The database provides occurrence data for 78 taxa, with 65 identified species and 13 categories to the genus level. Table 1 provides a preliminary listing of the nominate species mentioned and their current IUCN Redlist status and SPAW-II listing. At least one species included so far is actually not a seabird (Pandion haliaetus) but has been included because of its special interest.

The IUCN Redlist classifies the global conservation status of selected species. Most of the seabird species recorded in our overview fall under the category LC (Least Concern) based on their global population size (Table 1). Only three species are listed as species of concern in the Redlist. These are the Caribbean endemic Black-capped petrel, Pterdroma hasitata, the Leach's storm-petrel, Oceanodroma leucorhoa and the Atlantic yellow-nosed albatross, Thallasarche chlororhynchos. The SPAW (Specially Protected Areas and Wildlife) protocol of the Cartagena Convention is dedicated to biodiversity protection and has a different but partially overlapping selection of species offered legal protection. In doing so, it provides a legal framework for the conservation of regional biodiversity. The SPAW-listed species are the Black-capped petrel as above, the Audubon's shearwater, Puffinus Iherminieri, the Brown pelican, Pelecanus occidentalis, the Least tern, Sterna antillarum antillarum, and the Roseate tern, Sterna dougallii dougallii. The latter four are all considered LC in terms of their global status but were still considered of sufficient regional concern to be listed for the SPAW protocol.

With 30 species (33 taxa) the Laridae, representing gulls and terns is the most species-rich family (Table 2). Most records are available for the family Fregatidae, represented by only two species. Of these two, the Magnificent frigatebird, Fregata magificens, accounts for about $30 \%$ of the total data base (58,827 records). The Royal tern, Sterna maxima (Laridae), was second most numerous with 32,950 records, making up $75 \%$ of the Laridae. A good third was the Western osprey, Pandion haliaetus haliaetus $(28,249$ records).

Albatrosses (Diomedidae) are extremely rare in the area, with only four sightings of two species. These were the black-browed albatross (Thalassarche melanophris) (three sightings) and the Atlantic yellow-nosed albatross (Thalassarche chlororhynchos), the latter of which was one of the six species recorded only once (Table 3 ). 
Table 2. Seabird familial representation in the Caribbean Pelagic Seabird Map database.

\begin{tabular}{|l|c|c|c|}
\hline Family & $\mathrm{n}$ taxa & $\mathrm{n}$ species & N records \\
\hline Laridae & 33 & 30 & 43435 \\
\hline Procellariidae & 8 & 7 & 1263 \\
\hline Stercorariidae & 8 & 5 & 880 \\
\hline Sulidae & 6 & 4 & 12213 \\
\hline Fregatidae & 3 & 2 & 58840 \\
\hline Hydrobatidae & 3 & 2 & 107 \\
\hline Pelicanidae & 3 & 2 & 1916 \\
\hline Phaethontidae & 3 & 2 & 1628 \\
\hline Phalacrocoracidae & 3 & 2 & 502 \\
\hline Diomedeidae & 2 & 2 & 4 \\
\hline Oceanitidae & 2 & 2 & 114 \\
\hline Pandionidae & 2 & 2 & 29340 \\
\hline Scolopacidae & 2 & 2 & 130 \\
\hline
\end{tabular}

Table 3. Species for which only one record is yet available in the Caribbean Pelagic Seabird Map database.

\begin{tabular}{|l|l|l|l|l|}
\hline Species name & Scientific name & Year recorded & Location & Source \\
\hline $\begin{array}{l}\text { White-faced storm- } \\
\text { petrel }\end{array}$ & Pelagodroma marina & $18 . x i .1958$ & Hispaniola & RNBWS \\
\hline Common white tern & Gygis alba & $18 . i x .1962$ & Central Caribbean & RNBWS \\
\hline $\begin{array}{l}\text { Atlantic yellow-nosed } \\
\text { albatross }\end{array}$ & $\begin{array}{l}\text { Thalassarche } \\
\text { chlororhynchos }\end{array}$ & $19 . i x .1968$ & West off Grenada & RNBWS \\
\hline Sabine's gull & Xema sabini & $7 . v .1983$ & Cuba & RNBWS \\
\hline Mew gull & Larus canus & $10 . x i .1996$ & La Hispaniola & Observation.Org \\
\hline Northern gannet & Morus bassana & $7 . x i .2006$ & Cuba & Observation.Org \\
\hline
\end{tabular}

\subsection{Some preliminary patterns apparent}

Apart from the Saba Bank, which is a 2.2 thousand $\mathrm{km}^{2}$ area of principally shallow and shelf waters, the EEZ areas of the Dutch Caribbean fall principally in the pelagic zone of the Venezuela Basin. The best available preliminary insights into seabird distributions in these areas come from the seminal works of Halewijn (1972) and Poppe (1974). While seabird density and species richness appears highest closer to islands, several species seem to show a marked preference for the offshore waters. These include local breeders like: Sooty Tern, Red-footed Booby, Brown Noddy, and the visiting Pomerine Skua and Leach's Storm Petrel (Poppe 1974). The IUCN status for these species (except Leach's storm petrel, listed as VU) is LC (Table 1). The decreased density of seabirds offshore has been suggested to be partially due to the lower density of predatory fish (Boog et al. 2019) as pelagic seabirds may have to rely on other predators to drive fish schools (such as tuna's) to the surface (Ashmole and Ashmole 1967, Clay 1979).

Poppe (1974) observed that the Sooty Tern and the Red Footed Booby were by far most common species within the Venezuela Basin. Even based on scant data, large differences in seabird density and species composition between the northern and southern halves of the Venezuela Basin seem evident. So, for instance while Sooty Terns were sighted equally across the Venezuela Basin, Red Footed Boobies and Brown Noddies appear notably more abundant in the southern half of the Venezuela Basin. The higher density and species richness of seabirds in the southern half of the Venezuela Basin (north of the $A B C$ islands) may be due to the proximity of breeding areas such as the Aves and Los 
Roques archipelago's (for a recent review, see Debrot et al. 2019) or the higher productivity caused by the seasonal upwelling phenomenon of the southern Caribbean (Sturm 1991).

The Leeward Dutch Caribbean islands of Aruba, Bonaire and Curacao have long been recognized as a key Caribbean breeding area for several tern species (Halewijn \& Norton 1984, Debrot et al. 2009) but little is known about where these terns obtain their food or spend the rest of the year. The data we now accessed suggest that terns appear to be aggregating in large numbers along the north-western coast of Venezuela and the Guajira coast of Colombia. The coastal areas of La Guajira are a documented upwelling area (Paramo et al. 2003) and this suggests that possibly many of the locally breeding terns might be spending much time feeding in productive waters relatively nearby off Colombia and Venezuela.

Postma \& Nijkamp (1996) found that seabird densities on the Saba Bank averaged two times higher than off the Bank. On the Saba Bank most seabirds appeared to be concentrated around the $200 \mathrm{~m}$ isobath. The most common species they recorded (April-May) were Red-billed Tropicbird, Magnificent Frigate bird, Sooty Tern, and Bridled Tern. Other species were Pomerine Skua, and Wilson's Storm Petrel. In the pelagic areas adjacent to the bank, the Brown Noddy and Audubon's Shearwater were most common birds sighted. The IUCN status for these species is also LC.

All seabirds documented in the offshore EEZ areas so far are quite common (IUCN Red List status LC, least concern), with the exception of rare records for the Black Tern, Bulwer's Petrel and the endangered Black-capped Petrel (Prins et al. 2009). Given the low coverage of surveys (both in space and time) upon which the above information is based, dedicated surveys by trained seabird observers may well discover more of the less-common seabirds that have a more critical IUCN status. 


\section{$5 \quad$ Conclusions and recommendations}

In this project we provide many previously unavailable records of seabird distribution in the eastern Caribbean and integrate these data into previously existing databases on seabird distribution throughout the Caribbean. The combined database provides temporal and positional occurrence information for 65 nominate species and 13 larger familial or generic species groups in the Caribbean basin. The most important additions of previously unavailable records for the eastern Caribbean as brought in by this project were as follows: 2,894 records for Dutch Caribbean waters and adjacent areas as collected by Poppe (1974), Halewijn (1972) and de Boer and Saulino (unpublished), 547 records from Casler \& Lira (1979) and Casler \& Pirela (2004) for the north-western sector of Venezuela and 249 records from Naranjo (1979) and Estela et al. (2004) for the Caribbean coast of Colombia.

The study of at-sea ecology of seabirds has long trailed behind in comparison to other related fields such as the study of their terrestrial breeding habits. At-sea research of seabird distribution is also costly and complicated but still essential for a full appreciation of their role as predators and part of the food chain in the ecosystem (Ainley et al. 2012). Because of such complications, the study of seabird ecology is tending more and more towards high-tech detailed studies on individuals of certain species, still often based from breeding sites on land. However, at-sea observations for detailed observation of distribution and which allow "atlas-type" approaches as we aim to advance in this project, will remain invaluable for a true understanding of sea-bird community ecology, their roles in the pelagic ecosystem and for identifying seabird "hotspots" (Ainley et al. 2012). In this, a key recommendation would be to support the recording of any field observation to any bird species at sea in the region to leading recording platforms (e.g. eBird and Observation.org) as these records have shown to be the bulk of the data in the recent decades. Recording not only selected 'special encounters' but all birds at sea on the recording portals is highly recommended.

The data now complied and integrated can be used in different ways and for different purposes and provides a major new opportunity to study various aspects of seabird distribution in the coming years.

Potential topics for further study include:

1) the community composition of the pelagic seabirds of the Caribbean in comparison with the community structure of other pelagic seabird communities (e.g. Griffiths et al. 1982; Veit 1995)

2) how different habitat features (such as upwelling areas, proximity of nesting and/or roosting areas) are used by different species,

3) the identification of temporal trends in seabird species distribution and abundance,

4) habitat suitability modelling (e.g. Sahri et al. 2020) for identification of "hotspot" areas deserving conservation and management priority (e.g. Harris et al. 2007).

Our key recommendations for further follow-up work with the data compiled at this point are:

A) Use the combined data from the eastern Caribbean to verify and evaluate species distributions patterns as suggested by the unpublished studies of Poppe (1974) and Halewijn (1972).

B) Conduct preliminary mappings of species distributions as a first step to exploratory analysis of distributional patters and possible migration routes as well as in order to generate leads for further in-depth studies at the species or community levels. Species of initial interest would include: a) Royal tern, a breeding species, to be studied in relation to the known breeding colonies; Wilson's storm petrel for which there are a considerable number of sightings and for which distinction between it and Oceanodroma storm petrels may provide opportunities for improvement; Osprey for which there are very many records which might potentially allow the identification of migration routes of the North American subspecies. 
C) Incorporate GIS maps of marine bathymetry, primary productivity, areas of upwelling and nesting sites (e.g. Halewijn \& Norton 1984, Bradley \& Norton 2009) in order to facilitate the analysis of factors determining habitat use and regional differences in species distribution.

D) Use cluster analysis to detect possible community-level differences in the seabird populations of different areas of the Caribbean and to verify if there exists a "pelagic seabird community" in the Caribbean and if so, how it compares to the pelagic seabird communities of other larger oceanic areas.

E) Combine the data with the SovoN mapping project for land birds by expanding the maps to include marine areas. The focus of SOVON is the land birds of the 6 islands but with this data which provides positional data for so many species, the SOVON mapping project could be easily be expanded to include marine areas.

F) Provide the data for integration into the project Living Atlas of the Caribbean. The Living Atlas project is part of the multi-year Biodiversity Information for Development (BID) programme funded by the European Union and led by GBIF-the Global Biodiversity Information Facility. It has as its aim to expand the amount of biodiversity information available for use in scientific research and policymaking in the 'ACP' nations (sub-Saharan Africa, the Caribbean and the Pacific). 


\section{Acknowledgments}

We are grateful for funding support provided for this work by the Dutch Ministry of Agriculture, Nature and Food Security through the Kennis Basis programme of Wageningen University and Research:

KB36 Biodiversity in a Nature Inclusive Society project KB 36-005-002, "Nature Inclusive Transitions" (\#4318300121); and through their BeleidsOndersteuning/Policy Support project BO 43-021.04-004, Werelderfgoed Onderwaterpark Bonaire (4318100258). We thank Repsol Exploration Aruba S.A. for permission to include the previously unpublished data from the 2014 survey off Aruba.

\section{Author contributions}

Debrot: project conception, arranging funding, most writing, recovery and input of Spanish language records; Kaag: most data entry and data screening, writing; Leopold: lead in two first science publications, scrutiny of records, field survey records, editing; vd Wal: GIS mapping, figure; van Halewijn: field survey records; Poppe: field survey records; Verdaat: scrutiny of records, data entry, database integration, field survey records; Bazuin: database integration, data entry; Verweij: funding, editing, database management; de Boer: field survey records. 


\section{References}

Abdulla, A., Obura, D., Bertzky, B. and Shi, Y. (2013). Marine Natural Heritage and the World Heritage List: Interpretation of World Heritage criteria in marine systems, analysis of biogeographic representation of sites, and a roadmap for addressing gaps. IUCN, Gland, Switzerland. xii + 52pp.

Ainley, D. G., Ribic, C. A., \& Woehler, E. J. (2012). Adding the ocean to the study of seabirds: a brief history of at-sea seabird research. Marine Ecology Progress Series, 451, 231-243.

Ashmole, N. P \& Ashmole, M. J. (1967). Comparative feeding ecology of seabirds of a tropical oceanic island. Bull. Peabody Mus. Nat. Hist. 24, p. 97-99.

Beek, I.J.M., van. (2016). "Ecological values of the 12-mile zone of Bonaire." IMARES rapport C026/16. IMARES Wageningen UR. 34 pp.

Beek I.J.M., van, Cremer, J.S.M., Meesters, H.W.G., Becking, L.E. \& Langley, J.M. (2014). The potential Outstanding Universal Value and natural heritage values of Bonaire National Marine Park: an ecological perspective. IMARES Report number C145/14: $51 \mathrm{pp}$.

Boog, C. G., van der, de Jong, M. F., Scheidat, M., Leopold, M. F., Geelhoed, S. C. V., Schulz, K. \& Katsman, C. A. (2019). Hydrographic and biological survey of a surface-intensified anticyclonic eddy in the Caribbean Sea. Journal of Geophysical Research: Oceans, 124(8), 6235-6251.

Bradley P.E. \& Norton, R. L. (eds.) (2009). Breeding seabirds of the Caribbean. Univ. Press, Florida.

Chérubin, L. M., \& Richardson, P. L. (2007). Caribbean current variability and the influence of the Amazon and Orinoco freshwater plumes. Deep Sea Research Part I: Oceanographic Research Papers, 54(9), 1451-1473.

Clay, A. N. (1979). Isla de aves-a bird's eye view. New West Indian Guide/Nieuwe West-Indische Gids, 53(1), 85-101.

Cremer, J. \& Meesters, E. (2012). Bonaire National Marine Park (BNMP) op weg naar werelderfgoed. IMARES (University \& Research Centre) Report C140/12, 21 pp.

Debrot, A. O., J. A. de Meyer \& P. J. E. Dezentjé (1998). An overview of the cetacean fauna of the Leeward Dutch Antilles. Car. J. Sci. 34: 204-210.

Debrot, A. O., C. Boogerd \& D. van den Broeck (2009). Chapter 24. The Netherlands Antilles III: Curaçao and Bonaire. Pp. 207-215. In: P. E. Bradley and R. L. Norton (eds.) Breeding seabirds of the Caribbean. Univ. Press, Florida.

Debrot, A. O. \& Bugter, R. (2010). Climate change effects on the biodiversity of the BES islands: Assessment of the possible consequences for the marine and terrestrial ecosystems of the Dutch Antilles and the options for adaptation measures. Alterra-IMARES-report, Alterra Wageningen UR Wageningen, 2010, 34 pp.

Debrot, D., J. Langley, M. Vermeij, D. Slijkerman, R. Jongbloed, I. van Beek, J. de Freitas, L. Pors, R. Jak, C. Rockmann, J. Cremer (2018). Description of the Outstanding Universal Value (OUV) of the Proposed Marine Nomination Properties of the Bonaire and Curaçao Marine Parks (BCMP). Wageningen Marine Research (University \& Research Centre) Report C003/18: 184 pp. 
Debrot, A. O., A. Yranzo, \& D. Arocha (2019). Los Roques and Las Aves archipelagos, Venezuela: a marine ecological and conservation reconnaissance of two little-known southeastern Caribbean oceanic archipelagos, Atoll Research Bulletin 622:1-27.

Expertgroep (Expertgroep beoordeling werelderfgoednominaties) (2015). Bitter en Zoet: advies van de Expertgroep werelderfgoednominaties. Commissioned by the Netherlands Mininistry of Education Culture and Science. Bitter en Zoet, Veenhuizen. 79 pp,

Fratantoni DM (2001). North Atlantic surface circulation during the 1990's observed with satellitetracked drifters. Journal of Geophysical Research 106: 22067-22093

Griffiths, A. M., Siegfried, W. R., \& Abrams, R. W. (1982). Ecological structure of a pelagic seabird community in the Southern Ocean. Polar Biology, 1(1), 39-46.

Gyory J, Mariano AJ, Ryan EH (2005). "The Caribbean Current" Ocean Surface Currents. World wide web article, http://oceancurrents.rsmas.miami.edu/caribbean/caribbean.html

Halewijn, R. van, \& Norton, R. L. (1984). The status and conservation of seabirds in the Caribbean. Pp. 169-222 in Status and conservation of the world's seabirds (J. P. Croxall, P. G. H. Evans, and R. W. Schreiber, eds.). International Council for Bird Preservation Technical Bulletin no. 2. International Council for Bird Preservation, Cambridge, UK.

Harris J, Haward M, Jabour J \& Woehler EJ (2007). A new approach to selecting Marine Protected Areas (MPAs) in the Southern Ocean. Antarct Sci 19:189-194

Jongman, R.H.G., E.H.W.G. Meesters \& A.O. Debrot (2009). Onderzoeksvragen en verplichtingen op het gebied van Biodiversiteit voor de BES eilanden: Bonaire, Saba en St. Eustatius. Alterra-IMARES. 57 pp.

Keith, H. J. (20050. A simple synthesis of Caribbean geology. Transactions of the 16th Caribbean Geological Conference, Barbados. Caribbean Journal of Earth Science, 39: 69-82.

Leopold, M. F., Geelhoed, S. C., Scheidat, M., Cremer, J., Debrot, A. O., \& Van Halewijn, R. (2019). A review of records of the Black-capped Petrel Pterodroma hasitata in the Caribbean Sea. Marine Ornithology, 47, 235-241.

Lutz SJ, \& Ginsburg, R. N., (2007). State of deep coral ecosystems in the Caribbean Region: Puerto Rico and the US Virgin Islands. Pp 307-365. In: Lumsden SE, TF Hourigan, AW Bruckner, G Door (eds.) (2007) The state of deep coral ecosystems of the United States. NOAA Technical Memorandum CRCP-3. Silver Spring MD 365pp.

Mann, P. (1999). Caribbean Basins, Volume 4 (1st Ed.) Elsevier Science. ISBN: 9780080528595. 696 pp.

McGowan, A.,A.C. Broderick, S. Gore, G. Hilton, N.K. Woodfield \& B.J. Godley (2006). Breeding seabirds in the British Virgin Islands. End. Species. Res. 3: 15-20.

Meesters, H.W.G. D.M.E. Slijkerman, M. de Graaf, \& A.O. Debrot (2010). Management plan for the natural resources of the EEZ of the Dutch Caribbean. IMARES Rept. No. C100/10, 81 pp.

Paramo, J., Quiñones, R. A., Ramirez, A., \& Wiff, R. (2003). Relationship between abundance of small pelagic fishes and environmental factors in the Colombian Caribbean Sea: An analysis based on hydroacoustic information. Aquatic Living Resources, 16(3), 239-245. https://doi.org/10.1016/S09907440(03)00043-3 
Postma, T.A.C. \& Nijkamp, H. (1996). Seabirds, marine mammals and human activities on the Saba Bank. Field observations made during the Tydeman expedition, April-May 1996. AIDEnvironment, report $25 \mathrm{pp}$.

Prins, T.G., J.H. Reuter, A.O. Debrot, J. Wattel \& Nijman, V. (2009). Checklist of the birds of Aruba, Curacao, and Bonaire, South Caribbean. Ardea 97: 137-262.

Sahri, A., Putra, M. I., Mustika, P. L., \& Murk, A. J. (2020). A treasure from the past: Former sperm whale distribution in Indonesian waters unveiled using distribution models and historical whaling data. Journal of Biogeography.

Sturm, M. G. de L. (1991). The living resources of the Caribbean Sea and adjacent areas. Car. Mar. Stud. (1\&2): 18-44.

Veit, R. R. (1995). Pelagic communities of seabirds in the South Atlantic Ocean. Ibis, 137(1), 1-10.

Voous K.H. (1983). Birds of the Netherlands Antilles. Second edition. Walburg Pers, Zutphen.

Voous K.H. (1955). De vogels van de Nederlandse Antillen. Birds of the Netherlands Antilles. Uitgaven "Natuurwetenschappelijke Werkgroep Nederlandse Antillen", Curaçao, No. 5. 


\section{Justification}

Report C080/20

Project Number: 4318100258

The scientific quality of this report has been peer reviewed by a colleague scientist and a member of the Management Team of Wageningen Marine Research

Approved: $\quad$ Ir. R.J.H.G. Henkens

Specialist natuur, recreatie \& toerisme

Signature:

Date:

$25 / 09 / 2020$

Approved:

Drs. J. Asjes

Manager Integration

Signature:

Date:

$25 / 09 / 2020$ 
Wageningen Marine Research

T +31(0)317480900

E: marine-research@wur.nl

www.wur.eu/marine-research

Visitors' address

- Ankerpark 27, 1781 AG Den Helder

- Korringaweg 7, 4401 NT Yerseke

- Haringkade 1, 1976 CP IJmuiden
With knowledge, independent scientific research and advice, Wageningen Marine Research substantially contributes to more sustainable and more careful management, use and protection of natural riches in marine, coastal and freshwater areas.

Wageningen Marine Research is part of Wageningen University \& Research. Wageningen University \& Research is the collaboration between Wageningen University and the Wageningen Research Foundation and its mission is: 'To explore the potential for improving the quality of life' 